\title{
38. A HIGH RESOLUTION GEOPHYSICAL SURVEY OF DEEP SEA DRILLING PROJECT LEG 84 SITE $570^{1}$
}

\author{
A. M. Volpe, Geological Sciences, Scripps Institution of Oceanography \\ T. H. Shipley, Institute for Geophysics, University of Texas, Austin \\ and \\ G. F. Moore, Department of Geosciences, University of Tulsa ${ }^{2}$
}

\begin{abstract}
Numerous small canyons and gullies begin or end on the middle and upper continental slope off Guatemala suggesting rapidly varying depositional centers and erosional sites. Seismic data indicate downslope sediment transport and deposition on the midslope above a high-amplitude diffractive acoustic basement. Near Hole 570 acoustic basement is at a position and depth that corresponds to recovered serpentinites and serpentinized peridotites. The topographic high west of Site 570 is the source of a high-gradient magnetic anomaly, and on the basis of seismic and magnetic data it is interpreted to be an exposed outcrop of acoustic basement.
\end{abstract}

\section{INTRODUCTION}

We present the results of a detailed bathymetric, magnetic, and seismic survey of the seafloor surrounding Site 570 , located on the continental slope $70 \mathrm{~km}$ off the coast of Guatemala, $60 \mathrm{~km}$ northwest of San José Canyon, and $40 \mathrm{~km}$ upslope from the Middle America Trench. The survey (Figs. 1 and 2) was part of a high resolution study of sediment accretion and subduction in the Middle America Trench conducted aboard the Thomas Washington during the Ariadne Leg 3 (SIO-Scripps Institution of Oceanography) cruise, April 1982. The purposes of the survey were to determine the geologic setting of Site 570 , to better measure the magnetic field in order to determine the source of a high-gradient anomaly, and to obtain more information on slope sedimentary processes.

\section{DATA}

\section{Bathymetry}

Bathymetric swaths (Fig. 3) recorded by a multibeam echo sounder (Seabeam) were merged with corrected satellite navigation and plotted at a $20-\mathrm{m}$ contour interval. There were seven satellite-position fixes recorded during the survey with an average $50 \%$ error ellipse of $150 \times$ $320 \mathrm{~m}$. In several instances contours of adjacent and crossing swaths were matched by shifting ship tracks within the limits of the position errors.

The seafloor along the upper continental slope (200$1000 \mathrm{~m}$ depth) has high relief with deep $(200-500 \mathrm{~m})$ furrows aligned perpendicularly to the shelf edge. $\mathrm{Nu}$ merous small canyons and gullies, 400-2000 m wide and

\footnotetext{
${ }^{1}$ von Huene, R., Aubouin, J., et al., Init. Repts. DSDP, 84: Washington (U.S. Govt. Printing Office).

2 Addresses: (Volpe) Geological Sciences, A-008, Scripps Institution of Oceanography, University of California, San Diego, La Jolla, CA 92093; (Shipley) Institute for Geophysics, University of Texas, Austin, Austin, TX 78751; (Moore) Department of Geosciences, University of Tulsa, $600 \mathrm{~S}$. College Ave., Tulsa, OK 74104.
}

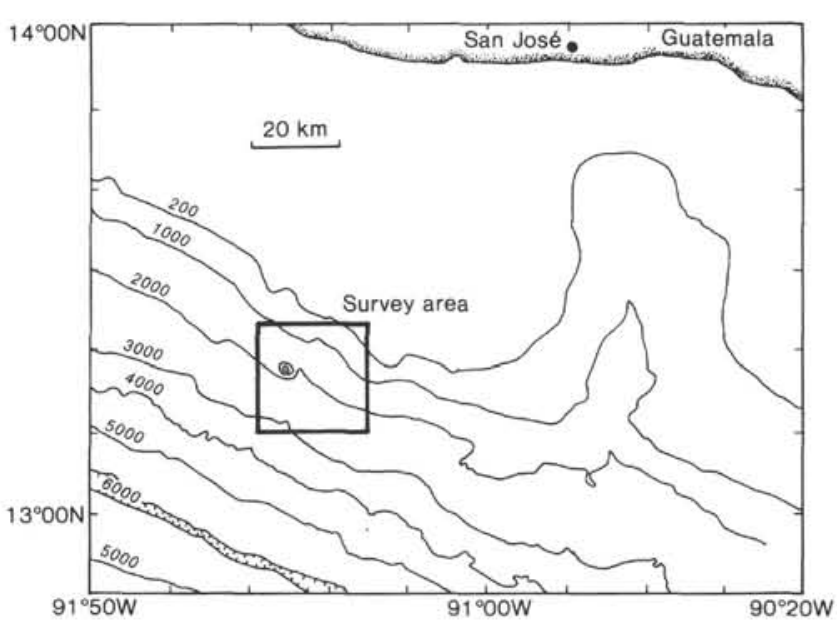

Figure 1. Bathymetry offshore Guatemala showing the location of the survey.

50-300 m deep, incise the middle slope (1000-3000 m depth). All are directed downslope, which is consistent with other observations of the slope made along the Middle America Trench (Fisher, 1961; Karig et al., 1978; Underwood and Karig, 1980). A deep (400 m) canyon is located 4 to $5 \mathrm{~km}$ east of Site 570 , and two canyons situated on either side of Site 570 coalesce downslope.

A prominent conical topographic high, having a basal diameter of $500 \mathrm{~m}$ and rising $500-950 \mathrm{~m}$ above the seafloor to a depth of $1130 \mathrm{~m}$, lies directly west $\left(13^{\circ} 17.6^{\prime} \mathrm{N}\right.$, $91^{\circ} 25.4^{\prime} \mathrm{W}$ ) of Site 570 . This bathymetric feature was recognized in a 1977 survey (Ladd et al., 1982) and is discussed in the following sections.

\section{Magnetic Survey}

Total-field magnetic anomaly magnitudes were generated by removal of the 1980 International Geomagnetic Reference Field from total-field magnetic readings. Magnitudes were plotted every $5 \mathrm{~min}$. $(1400 \mathrm{~m})$ on corrected 


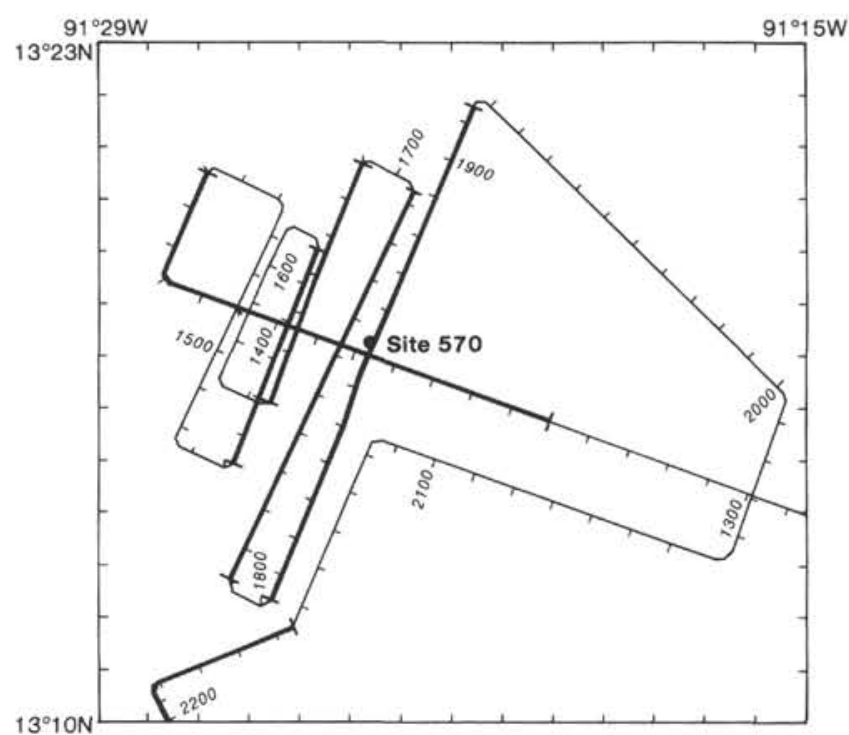

Figure 2. Track plot offshore Guatemala (15 April 1982, 1253-2200 GMT) showing tick marks every $5 \mathrm{~min}$. and hourly Greenwich Mean Time (GMT) annotations. Darkened segments represent seismic sections shown in Figures 5-10.

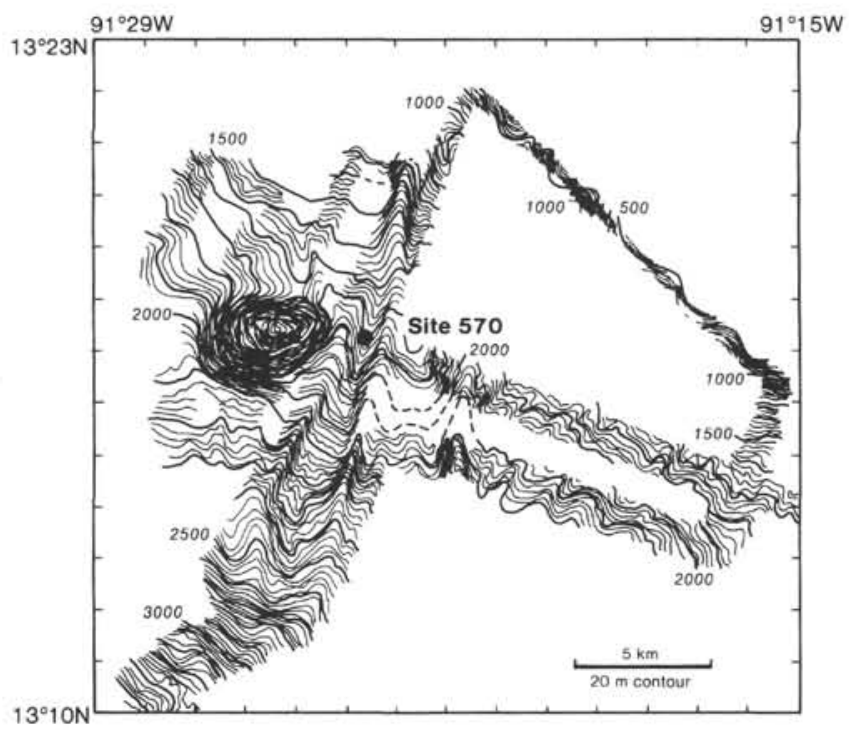

Figure 3. Bathymetry of seafloor around Site 570.

navigation tracks and contoured at a $20 \mathrm{nT}$ interval (Fig. 4). Analysis of anomaly magnitudes where the ship tracks crossed did not result in a predictable variation with time, and consequently no correction for solar diurnal variation was applied to the data. For most of the survey, magnitudes at the crossings have minor $(0-10 \mathrm{nT})$ mismatches. Magnetic anomalies along the upper slope (1910-2010 Greenwich Mean Time [GMT]) have large amplitudes and short wavelengths and were difficult to correlate with the other anomaly magnitudes.

The contoured anomalies confirm the dipolar pattern observed near Site 570 (Ladd et al., 1982) and indicate coincidence of an anomaly peak $(+354 \mathrm{nT})$ with the southern flank of the topographic high and an anomaly

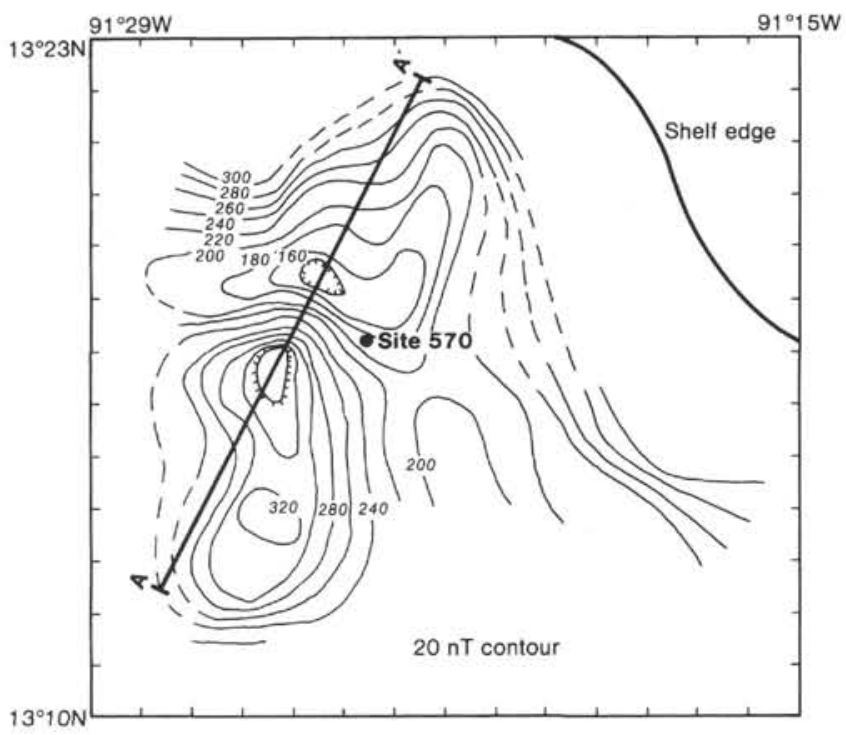

Figure 4. Total-field magnetic anomaly map contoured at a $20 \mathrm{nT}$ interval. Position of shelf edge is approximate and is from the bathymetry map of Ladd et al. (1982).

low (+134 nT) with a local accumulation of sediments northeast of the high. The gradient is steepest, with a $220 \mathrm{nT}$ offset and a separation of $3000-4000 \mathrm{~m}$, directly over the topographic high.

\section{Seismic Reflection}

Nine hours $(160 \mathrm{~km})$ of digital, single-channel, seismic reflection data were recorded employing two 80 -in. ${ }^{3}$ water gun acoustic sources. Bandpass filter $(20-100 \mathrm{~Hz})$ and automatic gain control $(0.5 \mathrm{~s})$ functions were used in processing done at SIO. The sharp water-gun pulse makes deconvolution unnecessary.

Acoustic basement off Guatemala (von Huene, Ladd, et al., 1982) is characterized on seismic records by highreflection amplitudes, a sharp to diffuse diffractive surface, lower frequency than the overlying coherent reflectors, and an absence of reflector continuity. The acoustic basement corresponds to serpentine and serpentinized peridotites drilled and recovered at five sites during Leg 84 (Aubouin et al., 1982; von Huene, Aubouin, et al., 1982). Figure 5 shows the acoustic basement at a position and depth $(2065-2090 \mathrm{~m})$ that is consistent with the basement sequence (serpentinized peridotite) recovered at Site 570 . Approximately $1 \mathrm{~km}$ west of Site 570 and $0.5 \mathrm{~km}$ east of the topographic high acoustic basement is within $0.1 \mathrm{~s}$ of the seafloor (Fig. 6; 1725 GMT). Acoustic basement shoals toward the base of the high, which is acoustically characterized by a distinct diffractive surface; high-amplitude, low-frequency reflectors; and an absence of reflector continuity beneath the diffractive surface (Figs. 7-9). These observations suggest that the topographic high is acoustically similar to and continuous with the acoustic basement surrounding Site 570 .

The low-amplitude reflectors occurring in sediments overlying the acoustic basement (Figs. 5-9) correspond to Cenozoic slope sediments (Aubouin et al., 1982; von Huene, Aubouin, et al., 1982; von Huene, Ladd, et al., 


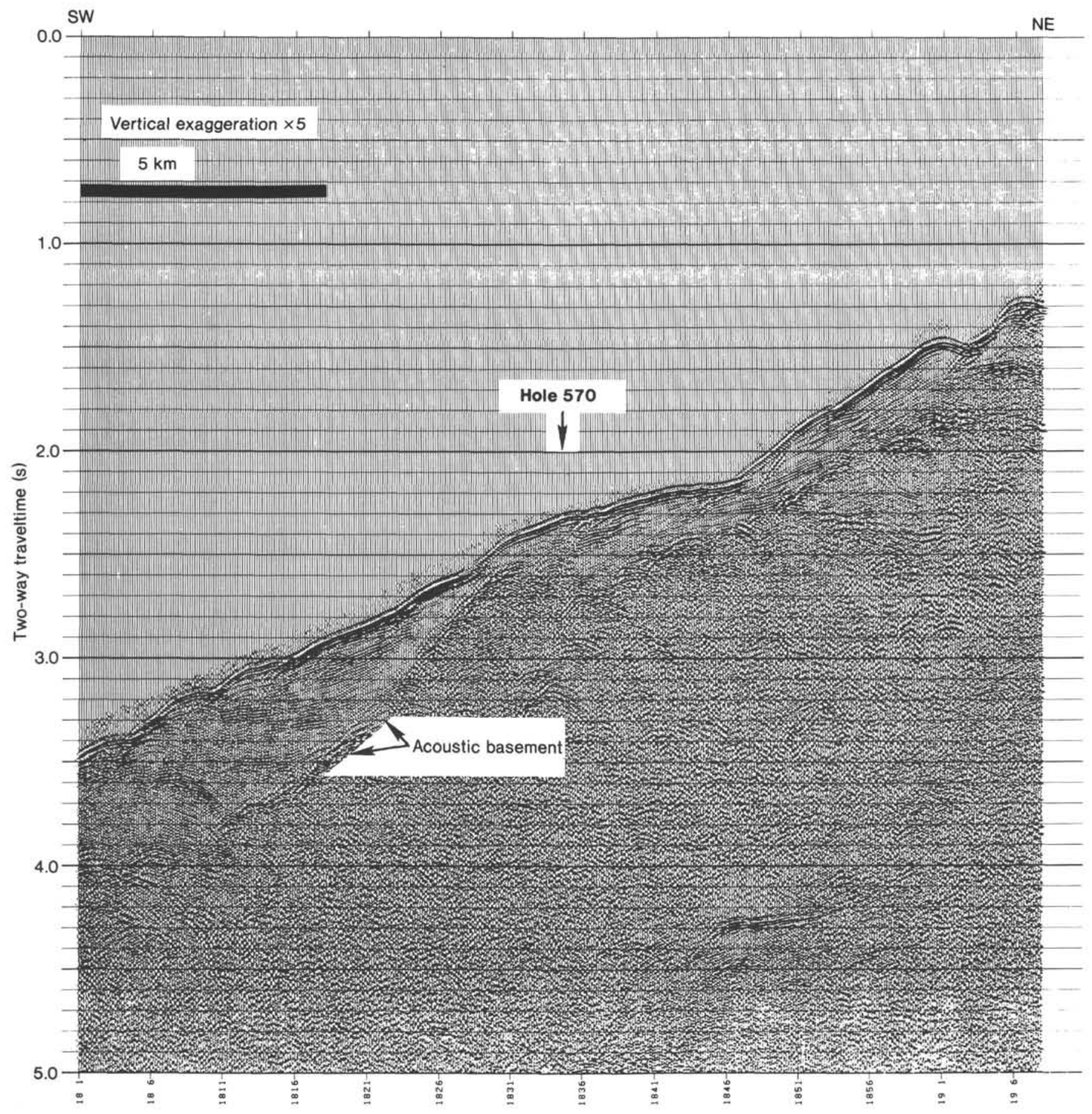

Figure 5. 1801-1906 GMT seismic record adjacent to Figure 6 showing position of Hole 570 and acoustic basement.

1982). Sediments recovered from Hole 570 include lower Eocene limestone and sandstone with a volcanic component, a thin lower Miocene horizon of black sandy mudstone overlain by upper Miocene green mud with rare horizons of sand, Pliocene mud with horizons of sand, and Pleistocene mud with locally thick layers of coarse sand.

Packets of low- and high-amplitude reflectors that have variable dips and lack reflection coherence in some sections are prevalent along the middle slope (Figs. 5 and 6) suggesting prograding slope sediments. Sediments fill several local topographic lows in the acoustic basement. The topographic low lying directly west of the high (Fig. 7; 1407-1415 GMT) extends beyond our survey preventing delineation of its boundaries. Another topographic low northeast of the high is associated with the low magnetic anomaly enclosure. Within this deposit sediments prograde downslope filling the depression and lap against the high.

A prograding deposit shown in Figure 10 is an example of the influence small canyons exert on slope deposition. The deposit is relatively thick and lies directly 
A. M. VOLPE, T. H. SHIPLEY, G. F, MOORE

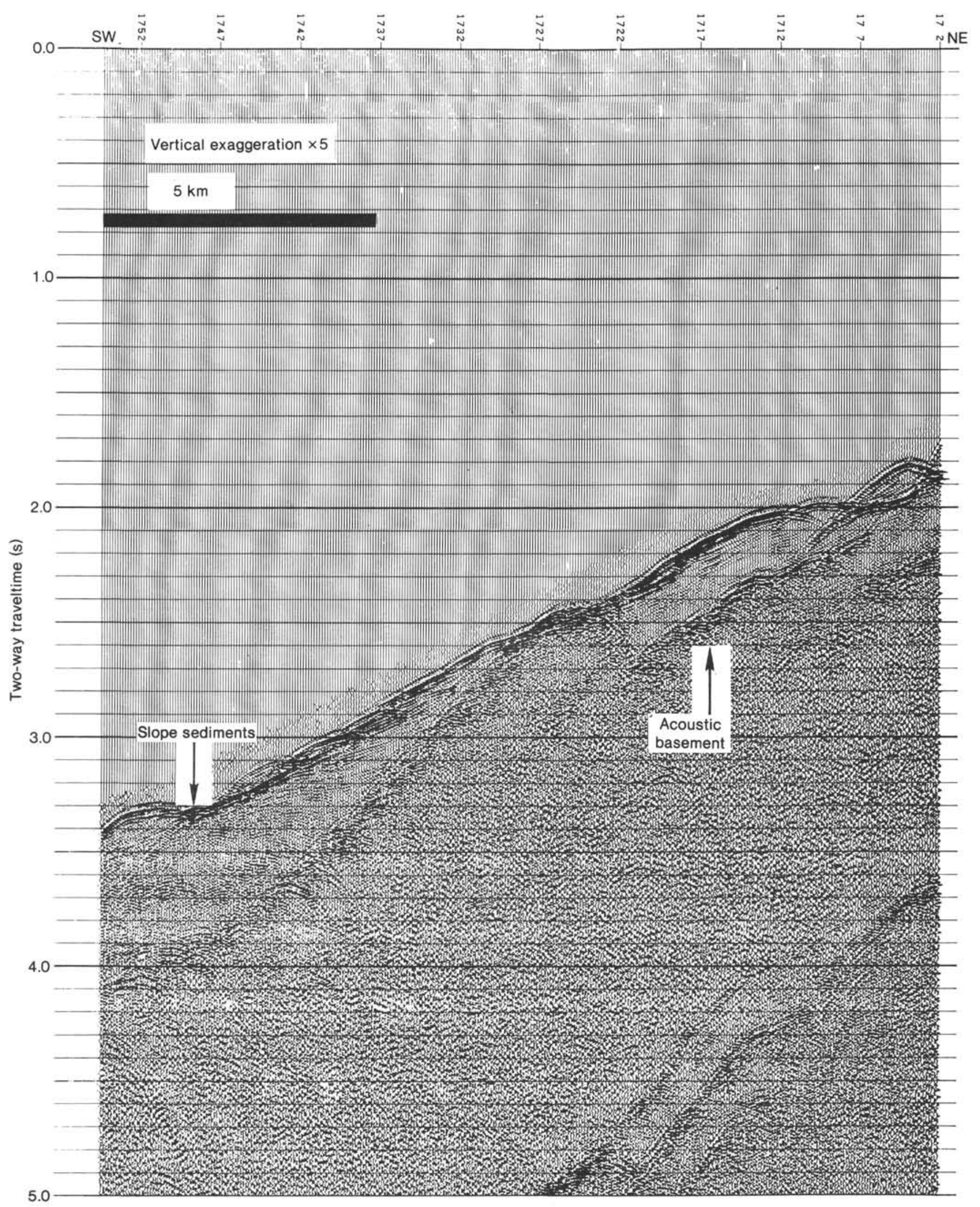

Figure 6. 1702-1755 GMT seismic record. Packets of prograding slope sediments overlying the diffractive acoustic basement, which is near the seafloor (1725 GMT). 


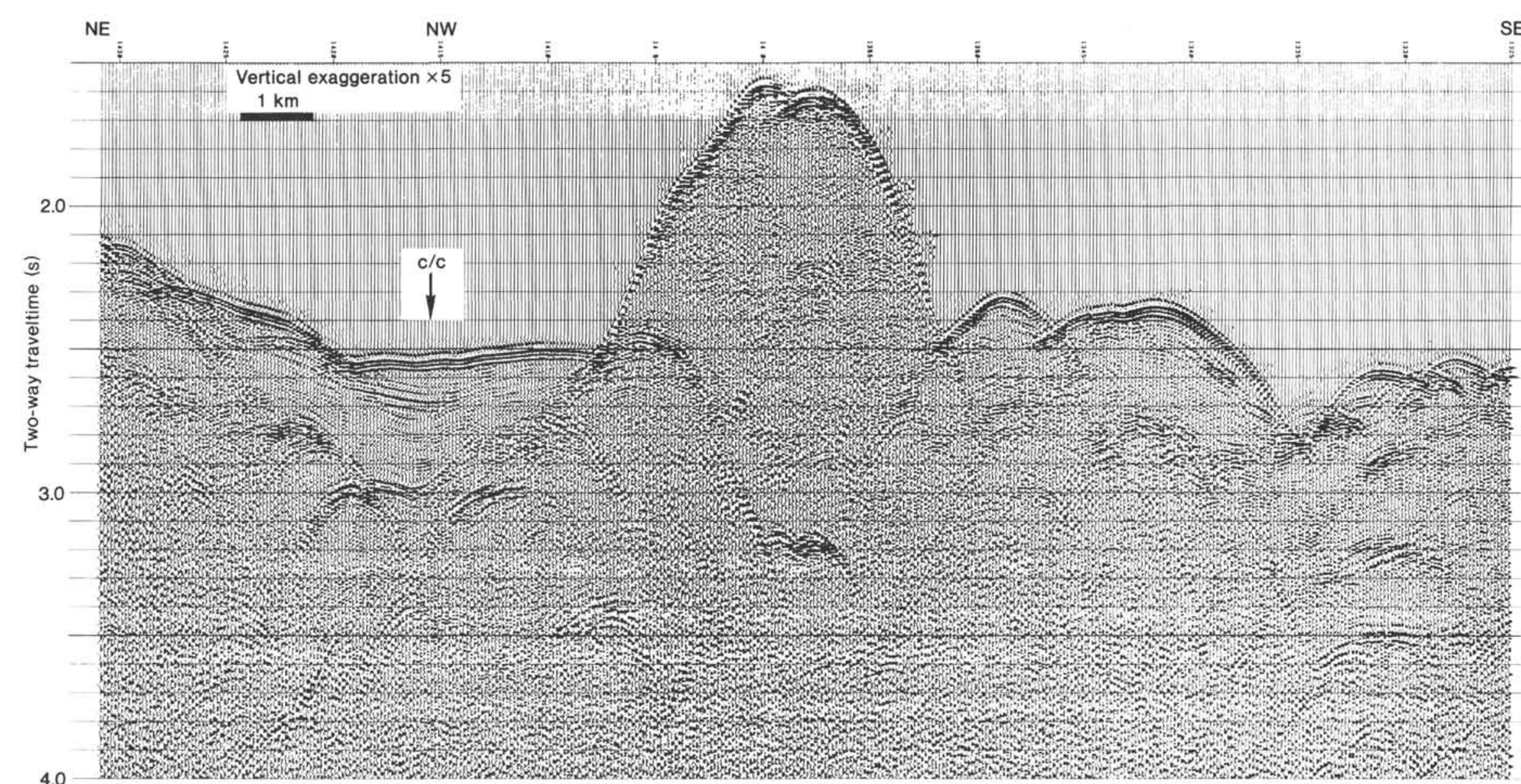

Figure 7. 1325-1430 GMT seismic record along the trench slope near Site 570 and across the topographic high. The course change (c/c) at 1415 GMT is $90^{\circ}$ in an upslope direction. 


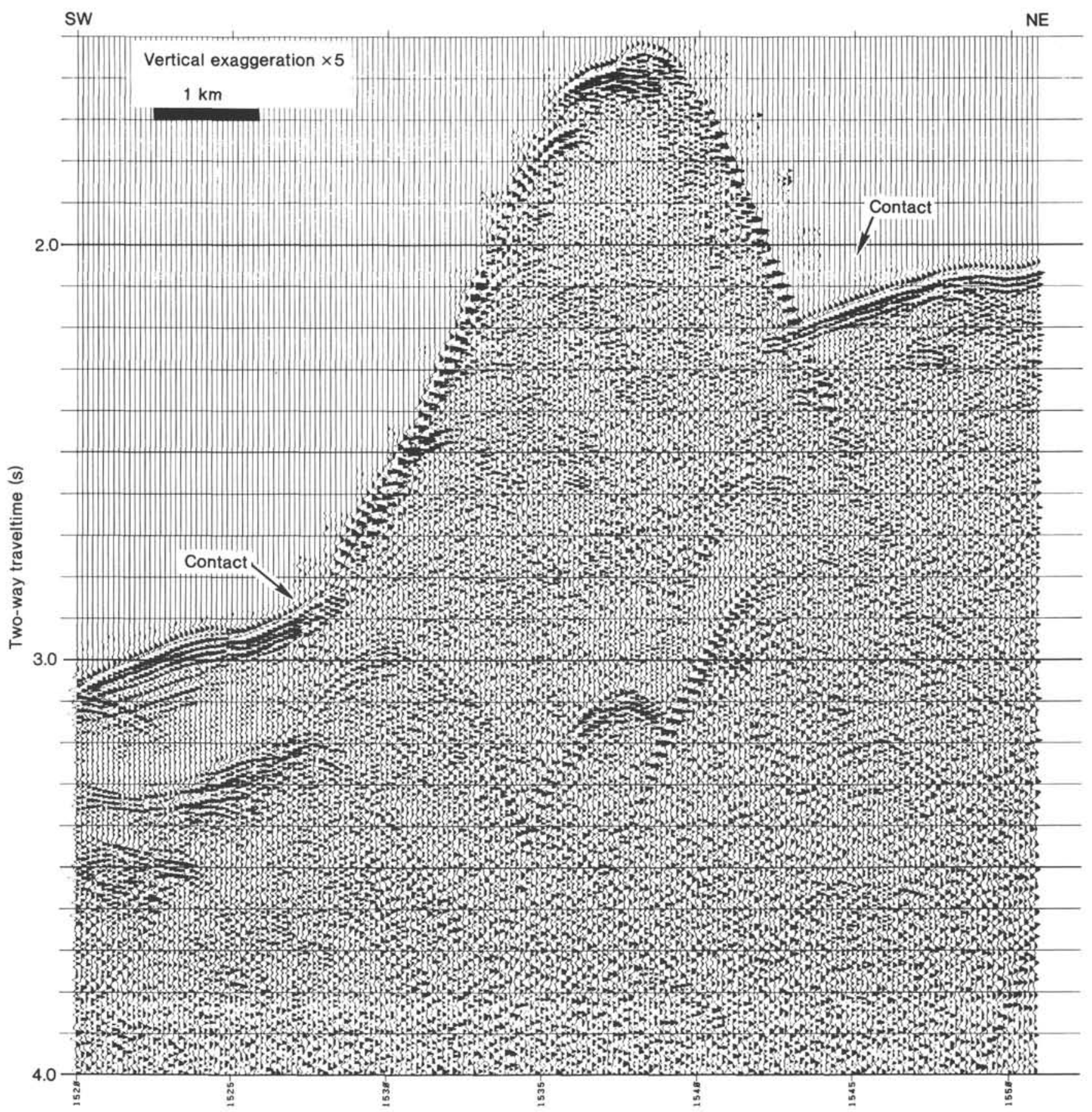

Figure 8. 1520-1550 GMT seismic record showing the contact between the slope sediments and the topographic high.

downslope of the area of coalescence of the two canyons passing to either side of Site 570 .

\section{DISCUSSION}

The high relief along the upper slope (200-1000 m) may have developed (1) by erosion of the shelf edge off Guatemala during glacial low sea-level stands (Seely, 1979; Underwood and Karig, 1980), (2) by mass movement processes at the shelf edge without subaerial exposure (Field and Clarke, 1979; Nardin et al., 1979; Underwood and Bachman, 1982), or (3) by some combination of both.
Because of insufficient survey coverage there is no clear indication of the extent to which mass movement processes along the upper slope initiate or participate in downslope sediment transport. The morphology of the middle slope (1000-3000 m) around Site 570 confirms previous observations that smaller canyons and gullies have an important influence on slope sediment distribution (Karig et al., 1978; Underwood and Karig, 1980; Underwood and Bachman, 1982). Many of these canyons and gullies begin or end within the survey area suggesting rapidly varying depositional centers and erosional sites. 


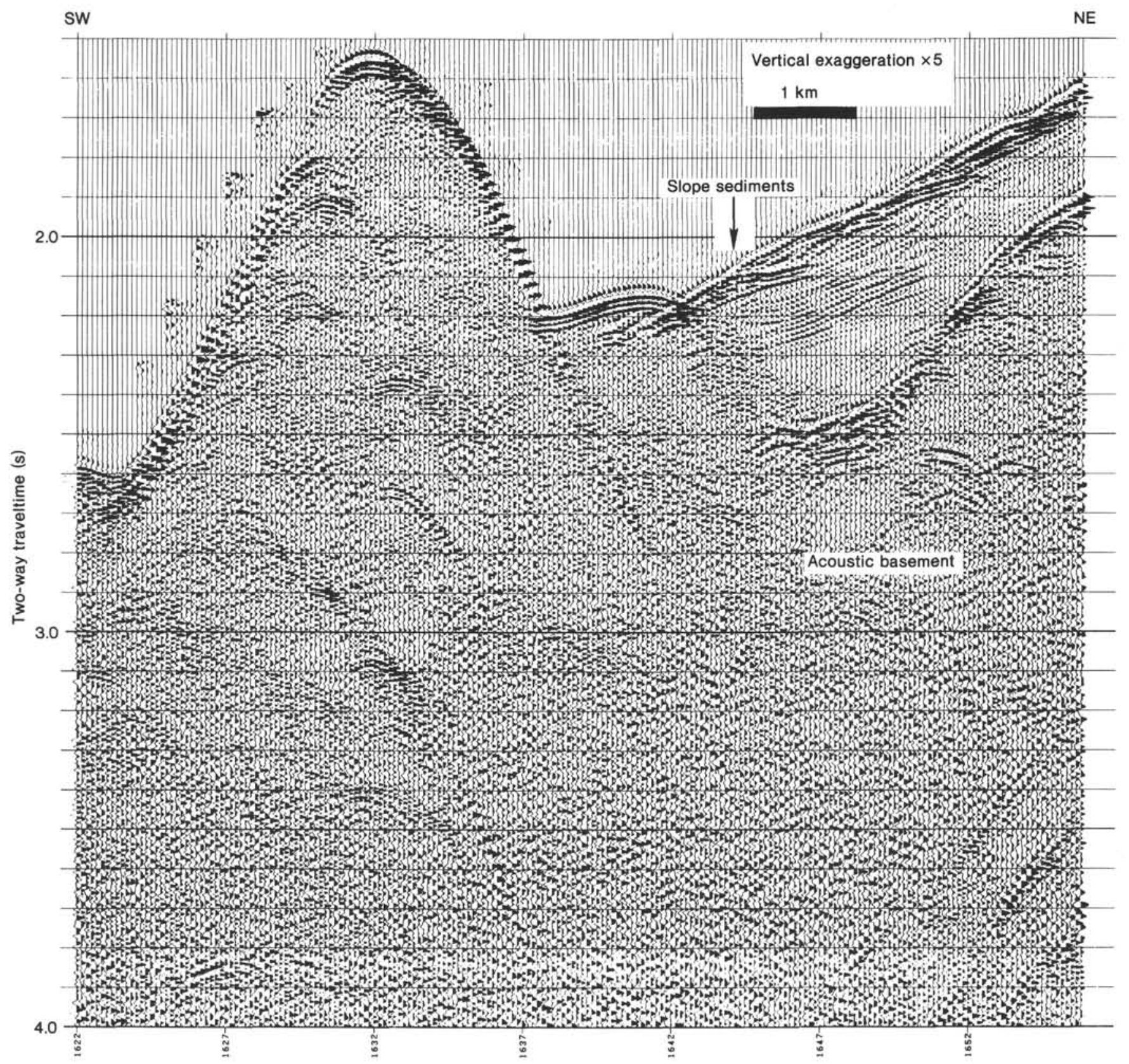

Figure 9. 1622-1656 GMT seismic record showing prograding slope sediments within a basement topographic low upslope from the high.

In regional surveys, modeling of lobate gravity highs (Couch and Woodcock, 1981) and magnetic and seismic data (Shor and Fisher, 1961; Seely, 1979; Ibrahim et al., 1979; Ladd et al., 1982) along the structural high off Guatemala suggests the presence of oceanic igneous rock in the subsurface similar to the ophiolitic sequences (Nicoya Complex) and serpentinized peridotite exposed on Nicoya and Santa Elena peninsulas in Costa Rica (Dengo, 1962). One hypothesis proposes (Dickinson and Seely, 1979; Seely, 1979) that the structural high off Guatemala flanks a residual forearc basin that formed above a remnant of oceanic lithosphere and began as a rupture within oceanic or transitional crust. In this hypothesis underthrusting of abyssal and trench sediments uplifted the outer edge of the residual forearc basin and resulted in a structural high. Another model (Lundberg, 1983) suggests that uplift of the forearc off Costa Rica was produced by vertical in-place stacking (telescoping) of forearc basement or by accretion of oceanic crust or both.

Investigation off Guatemala during Leg 67 (von Huene, Ladd et al., 1982) suggests that arching of the structural high along with subsidence of both the seaward and landward flanks occurred during the early Miocene. This would have been a separate event from the Paleocene uplift of the structural high (Seely, 1979). Seismic data (von Huene, Ladd, et al., 1982) indicate that the acoustic basement in the subsurface of the middle slope was 


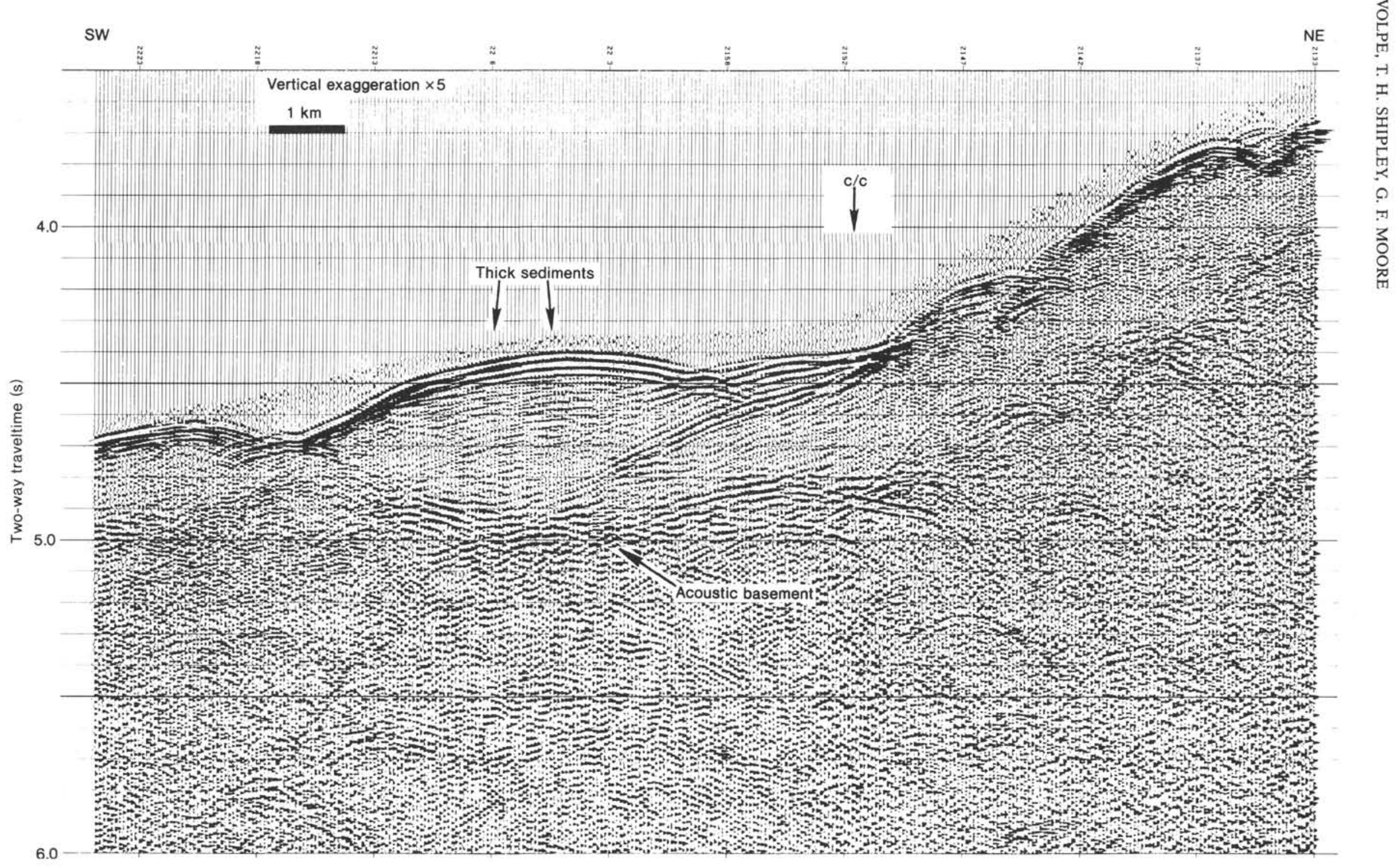

Figure 10. 2133-2225 GMT seismic record showing a thick accumulation of sediments deposited on a flat area of the acoustic basement. 
emplaced prior to deposition of the slope deposits and that there is an absence of Neogene imbrication coupled with the lack of a Neogene accretionary complex on the slope of the Middle America Trench off Guatemala.

Results from Leg 84 (Aubouin et al., 1982; von Huene, Aubouin, et al., 1982) indicate that recovered ophiolitic rocks corresponding to the acoustic basement on seismic records represent an oceanic crust emplaced in preearly Eocene. Decoupling in the subduction zone resulting from overpressurized pore fluids observed at Leg 84 sites may explain both the passive subduction of large topographic features on the oceanic plate and the subduction of abyssal and trench sediments beneath the emplaced oceanic crust rather than accretion to it (Aubouin et al., 1982).

In this context, we interpret the topographic high to be an exposed outcrop of acoustic basement. The evidence for this conclusion is based on seismic data and inferred from magnetic data. The acoustic basement shoals and approaches the seafloor westward from Site 570 to the base of the topographic high. The high is acoustically similar to and continuous with the acoustic basement around Site 570.

Prograding slope sediments lap against the topographic high. The sediments appear undisturbed and show no evidence of an intrusive relationship. Assuming that the slope sediments around the topographic high are coeval with sediments recovered from Site 570 , we conclude that the high, as well as the acoustic basement, was emplaced prior to Neogene slope sediment deposition.

While the source of the total-field magnetic anomaly is the topographic high, two-dimensional modeling (Fig. 11) allowing for a variable bottom topography suggests that the magnetic anomaly data can be explained by terrain effects without lateral variation in magnetic susceptibility, such as a difference in the composition between the topographic high and the surrounding basement. This is not a unique solution. The model utilizes a developed formulation (Parker, 1973; Parker et al., 1973) that derives the field resulting from a uniformly magnetized two-dimensional body in which the observation points lie within a plane $(x, z)$ everywhere above the material. We assume a block of material with a susceptibility of $24 \times 10^{-4} \mathrm{cgs}$ (serpentinized peridotite) and an upper surface matching the bathymetry.

The topographic high may be a remnant horst of Oligocene-Miocene faulting and subsidence of the seaward flank of the structural high that has not been covered by Neogene slope sediments. This interpretation is consistent with the high relief of the acoustic basement $(1000 \mathrm{~m})$ underlying the slope deposits on the middle slope off Guatemala seen on seismic records (von Huene, Ladd, et al., 1982) (Fig. 4). Also, it is analogous to information obtained from surveys off the Marianas where dredging of topographic highs coinciding with gravity and magnetic anomaly highs along the slope break recovered serpentine-rich sediments and serpentinized peridotite (Evans and Hawkins, 1979; Bloomer and Hawkins, 1982).

\section{ACKNOWLEDGMENTS}

We are grateful to Eli Silver and John Ladd for reviewing the manuscript. Many thanks to Perry Crampton and Paul Henkart for profi-
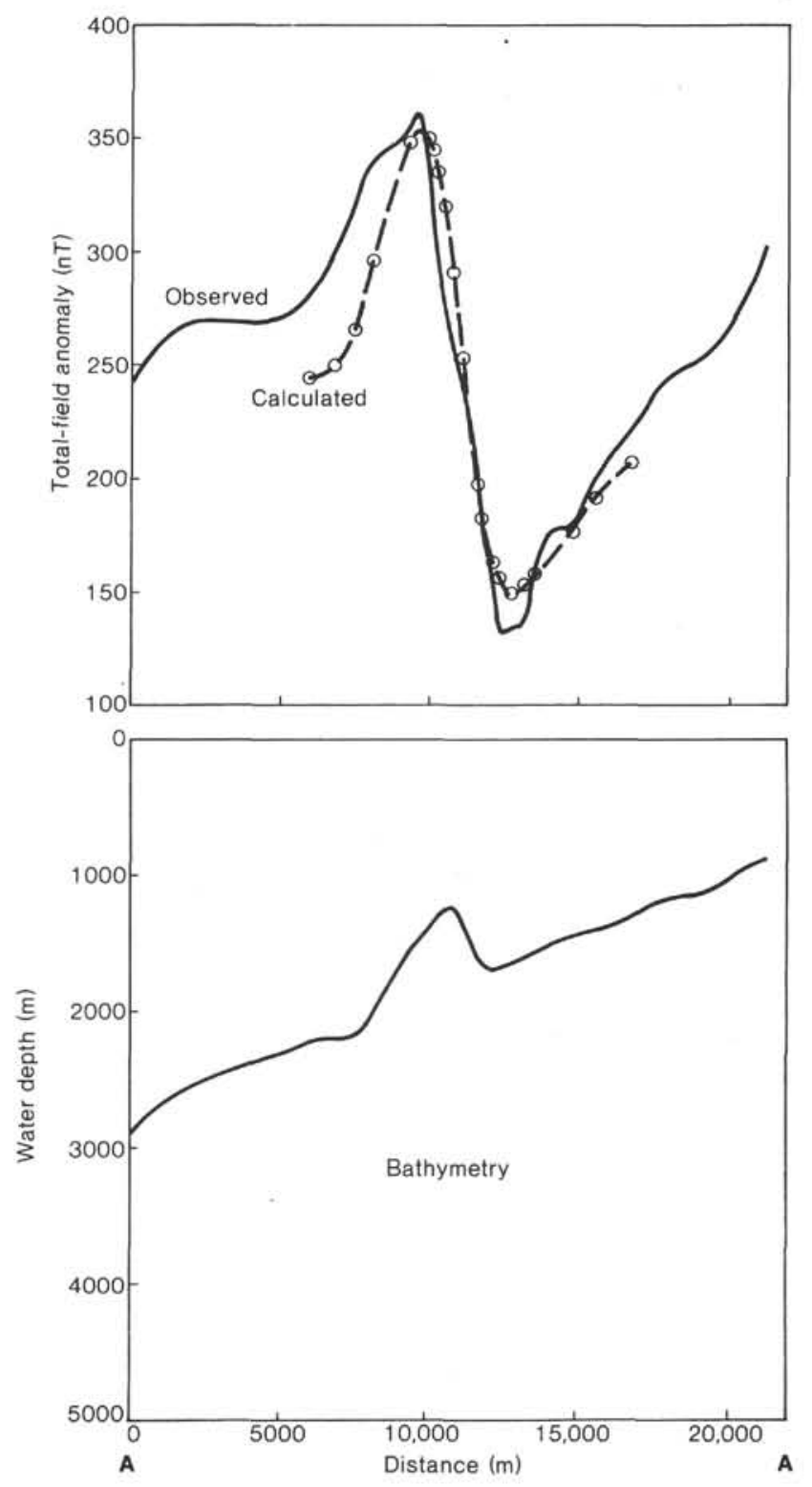

Figure 11. Total-field magnetic anomaly profile and bathymetric profile along section $\mathrm{A}-\mathrm{A}^{\prime}$. Anomaly magnitudes were calculated using a model with uniform magnetization and susceptibility of 24 $\times 10^{-4} \mathrm{cgs}$.

ciency, patience, perseverance, and timely humor. This research was supported by a National Science Foundation grant (OCE80-24402) to Shipley and Moore.

\section{REFERENCES}

Aubouin, J., von Huene, R., Baltuck, M., Arnott, R., Bourgois, J., et al., 1982. Leg 84 of the DSDP, subduction without accretion: Middle America Trench of Guatemala. Nature, 297:458-460.

Bloomer, S. H., and Hawkins, J. W., 1982. Gabbroic and ultramafic rocks from the Mariana Trench: an island arc ophiolite. In Hayes, D. E. (Ed.), The Tectonic and Geologic Evolution of Southeast Asian Seas and Islands, Part 2. Geophys. Mono. Ser., 27:294-317.

Couch, R., and Woodcock, S., 1981. Gravity and structure of the continental margins of southwestern Mexico and northwestern Guatemala. J. Geophys. Res., 86:1829-1840.

Dengo, G., 1962. Tectonic-igneous sequence in Costa Rica. In Engel, A. E., James, H. L., and Leonard, B. F. (Eds.), Petrologic Studies: a Volume in Honor of A. F. Buddington. Geol. Soc. Am., pp. 133-161. 
Dickinson, W. R., and Seely, D. R., 1979. Structure and stratigraphy of forearc regions. Am. Assoc. Petrol. Geol. Bull., 63:2-31.

Evans, C. A., and Hawkins, J. W., 1979. Mariana arc-trench system: petrology of "seamounts" on the trench slope break. EOS Trans. $A G U, 60: 968$. (Abstract).

Field, M. E., and Clarke, S., 1979. Small scale slumps and slides and their significance for basin slope processes, Southern California Borderland. In Doyle, L. J., and Pilkey, O. H. (Eds.), Geology of Continental Slopes. Soc. Econ. Paleontol. Mineral. Spec. Publ., 27:223-230.

Fisher, R. L., 1961. Middle America Trench: topography and structure. Geol. Soc. Am. Bull., 72:703-720.

Ibrahim, A., Latham, G., and Ladd, J., 1979. Seismic refraction and reflection measurements in the Middle America Trench offshore Guatemala. J. Geophys. Res., 84:5643-5650.

Karig, D. E., Cardwell, R. K., Moore, G. F., and Moore, D. G., 1978. Late Cretaceous subduction and continental margin truncation along the northern M.A.T. Geol. Soc. Am. Bull., 89:265-276.

Ladd, J., Ibrahim, A., McMillen, K., Latham, G., and von Huene, R., 1982. Interpretation of seismic reflection data of the Middle America Trench off Guatemala. In Aubouin, J., von Huene, R., et al., Init. Repts DSDP, 67: Washington (U.S. Govt. Printing Office), 675-690.

Lundberg, N., 1983. Development of forearcs of intraoceanic subduction zones. Tectonics, 2:51-61.

Nardin, T. R., Edwards, B. D., and Gorsline, D. S., 1979. Santa Cruz Basin, California Borderland: dominance of slope processes in basin sedimentation. In Doyle, L. J., and Pikley, O. H. (Eds.), Geology of Continental Slopes. Soc. Econ. Paleontol. Mineral. Spec. Publ., 27:209-222.
Parker, R. L., 1973. The rapid calculation of potential anomalies. Geophys. J. R. Astron. Soc., 31:447-455.

Parker, R. L., Mudie, J. D., and Howard, R. S., 1973. Another method for calculating magnetic anomalies. Scripps Institution of Oceanography Reference Series 73-2, University of California, San Diego, California.

Seely, D. R., 1979. The evolution of structural highs bordering major forearc basins. In Watkins, J. S., and Montadert, L. (Eds.), Geological and Geophysical Investigation of Continental Margins. Am. Assoc. Petrol. Geol. Mem., 29:245-260.

Shor, G. G., and Fisher, R. L., 1961. Middle America Trench: seismic refraction studies. Geol. Soc. Am. Bull., 72:721-730.

Underwood, M. B., and Karig, D. E., 1980. Role of submarine canyons in trench and trench-slope sedimentation. Geology, 8: 432-436.

Underwood, M. B., and Bachman, S. B., 1982. Sedimentary facies associations within subduction complexes. In Leggett, J. K. (Ed.), Trench, Forearc Geology. Geol. Soc. London Spec. Publ., 10: 537-550.

von Huene, R., Aubouin, J., Baltuck, M., Arnott, J., Bourgois, J., et al., 1982. Preliminary results, DSDP Leg 84, Middle America Trench off Guatemala. Am. Assoc. Petrol. Geol., 66(10):1702.

von Huene, R., Ladd, J. W., and Norton, I., 1982. Geophysical observations of slope deposits, Middle America Trench off Guatemala. In Aubouin, J., von Huene, R., et al., Init. Repts. DSDP, 67: Washington (U.S. Govt. Printing Office), 719-732.

Date of Initial Receipt: 21 December 1983 Date of Acceptance: 1 February 1984 